ZOOLOGIA 32 (1): 33-40, February 2015

http://dx.doi.org/10.1590/S1984-46702015000100005

\title{
Description of the first species of Metharpinia (Crustacea: Amphipoda: Phoxocephalidae) from Brazil
}

\author{
Luiz F. Andrade' ${ }^{1}$ Rodrigo Johnsson ${ }^{2} \&$ André R. Senna ${ }^{2}$
}

\begin{abstract}
${ }^{1}$ Programa de Pós-graduação em Biologia Animal, Universidade Federal Rural do Rio de Janeiro. Rodovia BR 465, km 7, 23890-000 Seropédica, RJ, Brazil. E-mail: Izflp.andrade@hotmail.com

2Laboratório de Invertebrados Marinhos: Crustacea, Cnidaria \& Fauna Associada, Instituto de Biologia, Universidade Federal da Bahia. Rua Barão de Jeremoabo 147, Ondina, 40170-290 Salvador, BA, Brazil. E-mail: r.johnsson@gmail.com; senna.carcinologia@gmail.com
\end{abstract}

\begin{abstract}
A new amphipod species of Metharpinia Schellenberg, 1931 is described from Campos Basin, southeastern Brazilian coast. The material was collected with van Veen grab from unconsolidated substratum, off the mouth of the Paraíba do Sul River. The new species can be distinguished from its congeners by presenting a strongly constricted rostrum and a slender palp of maxilla 1. There are four species in Metharpinia from the South Atlantic: M. dentiurosoma Alonso de Pina, 2003, M. grandirama Alonso de Pina, 2003 and M. iado Alonso de Pina, 2003, and Metharpinia taylorae sp. nov. This is the first record of a species of the genus from Brazilian waters.
\end{abstract}

KEY WORDS. Amphipod; Campos Basin; Habitats Project; Metharpinia taylorae sp. nov.; taxonomy.

Phoxocephalidae Sars, 1895, one of the most diverse amphipod taxa in terms of taxonomic characters, is characterized by the following: antennae 1 and 2 haustorioid in shape and with multiarticulate accessory flagellum; gnathopods 1 and 2 subchelated or chelated; pereopod 7 distinct from pereopod 5-6, shortened, article 2 expanded posteriorly; uropod 3 biramous; telson deeply cleft (BARNARD \& DRUMMOND 1978, 1982). The Phoxocephalidae are benthic-burrowing amphipods (HurLey 1954). They are widely distributed from shallow to deep waters. According to BARNARD \& DRUMMOND (1978), Australia is the evolutionary center of the Phoxocephalidae, and there are two areas of dispersion of shallow water phoxocephalids, the Magellanic region plus the Falkland islands, and the Antarctica (including South Geogia Islands). However, this hypothesis needs to be tested by modern phylogenetic methods.

Phoxocephalidae currently includes more than 460 species around the world, grouped in 11 subfamilies and 74 genera (Horton \& De Broyer 2014). Most species are found exclusively in the deep sea of the southern hemisphere (BARNARD \& Drummond 1978). According to SenNa \& SouZa-FilHo (2011) there are 13 Phoxocephalidae species recorded from Brazilian waters: Bathybirubius margaretae Senna, 2010, Coxophoxus alonso Senna, 2010, Harpiniopsis galera Barnard J.L., 1960, Hererophoxus videns Barnard KH, 1930, Leptophoxoides marina Senna, 2010, Microphoxus breviramus Bustamante, 2002, M. cornutus (Schellenberg, 1931), M. moraesi Bustamante, 2002, M. uroserratus Bustamante, 2002, Phoxocephalus homilis Barnard JL, 1960, Pseudharpinia berardo Senna, 2010, P. ovata Senna, 2010, and P. tupinamba Senna \& Souza-Filho, 2011.
Metharpinia Schellenberg, 1931 and its sister-group, Microphoxus Barnard, 1960, are among the most primitive genera in the birubiin-parharpiniin group of the Americas. Metharpinia has nine species, all distributed along the west and east coasts of North and Central America, and Argentina (Barnard \& Drummond 1978, Barnard \& Karaman 1991, Alonso De Pina 2001, 2003a, b). According to Alonso de Pina (2003a), species of Metharpinia are characterized by the following characters: antenna 1, article 2 with ventral setae placed proximally; maxilliped with dactylar nail partially fused and immersed; gnathopods 1 and 2, palms acute and propodus poorly setose anteriorly; and pereopods 3 and 4, propodus with facial setal formula composed of stout setae and dactyli with inner acclivity sharp, produced as tooth.

We describe a new species of Metharpinia. This is the first record of the genus from Brazilian waters, increasing the Phoxocephalidae diversity in Brazil to 14 species in nine genera.

\section{MATERIAL AND METHODS}

The material examined was collected during the Habitats Project (Environmental Heterogeneity of Campos Basin), coordinated by the Brazilian Oil Company (CENPES/ PETROBRAS). Collecting trips were conducted at the Campos Basin, off the mouth of the Paraíba do Sul River, between the states of Rio de Janeiro and Espírito Santo, southeastern Brazil, in the Summer and Winter of 2009. Collections were made aboard of the R/V Gyre, from unconsolidated substratum, using a van Veen grab.

2015 | Sociedade Brasileira de Zoologia | www.sbzoologia.org.br | www.scielo.br/zool All content of the journal, except where identified, is licensed under a Creative Commons attribution-type BY-NC. 
The specimens were dissected under a stereoscopic microscope Motic K-401L and mounted in glycerine gel slides. The illustrations were produced under an optic microscope with a camera lucida Motic BA-310. The type material is deposited at the Crustacea Collection of the Museu Nacional, Universidade Federal do Rio de Janeiro (MNRJ). It is preserved in 70\% ethanol or glycerine gel slides. The setal classification adopted in this paper follows WatLing (1989). Nomenclature of the gnathopod palm is based on Poore \& Lowry (1997).

\section{TAXONOMY}

Metharpinia Schellenberg, 1931

Diagnosis. See Barnard \& Karaman (1991).

Composition of the genus: M. coronadoi Barnard, 1980; M. dentiurosoma Alonso de Pina, 2003; M. floridana (Shoemaker, 1933); M. grandirama Alonso de Pina, 2003; M. iado Alonso de Pina, 2003; M. jonesi (Barnard, 1963); M. longirostris Schellenberg, 1931; M. oripacifica Barnard, 1980; M. protuberantis Alonso de Pina, 2001; M. taylorae sp. nov.

\section{Metharpinia taylorae sp. nov. Figs. 1-25}

Diagnosis. Rostrum strongly constricted. Right mandible, incisor with two spines, one large, apically bifid, and one small and subrounded. Left mandible, incisor with three teeth, one large and two small, one of them apically bifid, lacinia mobilis well developed, apically smooth and subrounded. Maxilla 1, palp very slender and setose. Maxilliped, inner plate with three apical plumose setae. Gnathopods 1-2 poorly setose. Pereopod 7, basis with posteroventral lobe rounded. Epimeral plate 3, ventral margin with five submarginal pectinate setae, posterior margin slightly serrate, with 13 long slender setae, posteroventral corner broadly rounded. Urosomite 3 without dorsal hook. Uropod 3, inner ramus bearing few plumose setae, outer ramus with one plumose seta. Telson, deeply cleft, about $90 \%$ of its length, apical margin sinuous, each lobe with one lateral small plumose seta, subapical margin bearing five slender setae on each lobe, inner teeth of apex naked.

Description. Based on the holotype (MNRJ 477) and allotype (MNRJ 479). Head (Figs. 1 and 2), eyes present, rostrum strongly constricted, narrow, spatulate, elongate, about $1.3 \mathrm{X}$ longer than antenna 1 peduncular article 1 . Antenna 1 (Fig. 3 ), peduncle article 1 about $1.4 \mathrm{X}$ longer than wide, without setae; article 2 anterodorsal corner with one small slender seta, ventral margin with seven slender setae, $1.3 \mathrm{X}$ longer than wide; article 3 shortened with two ventral slender setae, $1.2 \mathrm{X}$ wider than long; flagellum 16-articulate, poorly setose; accessory flagellum 14-articulate, elongate, poorly setose. Antenna 2 (Fig. 4 ), peduncle, article 4 about $1.5 \mathrm{X}$ longer than wide ventral margin with a row of 10 slender setae, 11 stout facial setae arranged in three rows, anterodorsal corner with one stout seta and one simple seta; article 5, ventral margin setose, facial row of setae with nine medium to small stout setae, apical margin with two medium slender setae; flagellum 20-articulate, poorly setose. Right mandible (Fig. 5), incisor with two teeth, one large, apically bifid, and one small and blunt; accessory setal row with seven stout multi-cuspidate setae; molar not triturative with four slender setae; palpar hump small, lacinia mobilis absent, palp 3articulate, article 3 apically setose. Left mandible (Fig. 6), incisor with three teeth, one large and two small, one of them apically bifid; accessory setal row with eight stout multi-cuspidate setae; molar not triturative, with nine apical slender setae; lacinia mobilis well developed, apically smooth and subrounded. Maxilla 1 (Fig. 7), inner plate $1.1 \mathrm{X}$ wider than long with five apical plumose setae; outer plate $1.3 \mathrm{X}$ longer than wide with 10 multicuspidate robust apical setae; palp 2-articulate, very slender, article 2 , outer margin with five slender setae, three proximal and two distal, inner margin with four slender setae, and apical margin with three slender setae. Maxilla 2 (Fig. 8), inner plate about 1.6X longer than wide and slightly shorter than outer plate, apical margin with nine slender setae; outer plate about 2.6X longer than wide, apical margin with eight slender setae. Maxilliped (Fig. 9), inner plate subrectangular, with three apical plumose setae; outer plate lanceolate with seven medial setae, two apical setae, and one small lateral setae; palp, 4-articulate, article 2 , suboval, about $2.2 \mathrm{X}$ longer than wide medially setose; article 3 suboval, medially setose, with one lateral slender setae in notch, about 1.9X longer than wide; article 4 simple, curved and slender.

Gnathopod 1 (Fig. 10) poorly setose, coxa weakly expanded anteriorly, posteroventral corner with six slender setae; basis about $3.5 \mathrm{X}$ longer than wide, subrectangular, posterior margin with 13 short slender setae, ventral margin without setae; ischium, small, posteroventral corner with three slender setae; merus, small, subtriangular, posterior margin with three slender setae; carpus, about $1.4 \mathrm{X}$ longer than wide posterior margin medially setose; propodus, about $1.4 \mathrm{X}$ longer than wide, anterior margin without setae, anterodistal corner with four slender setae, posterior margin straight with 10 slender setae, palm almost transverse, palmar corner defined by a small and slightly upwards curved spine with one lateral stout seta with accessory seta; dactylus, curved, simple, subequal in length to palm. Gnathopod 2 (Fig. 11) poorly setose, coxa weakly expanded anteriorly, posteroventral corner with 12 slender setae, posterior margin with two pairs of small slender setae, anterior margin with one pair of small slender setae; basis about 4.1X longer than wide, subrectangular, anterior margin with two slender setae, anteroventral corner with six slender setae, posterior margin with two slender setae; ischium, small, without setae; merus, small, subtriangular, posterior margin with six slender setae; carpus, elongate, about $3 \mathrm{X}$ longer than wide posterior margin setose; propodus, about $1.9 \mathrm{X}$ longer than wide, anterodistal corner setose, posterodistal margin setose, palm almost transverse, palmar corner defined by a small spine 


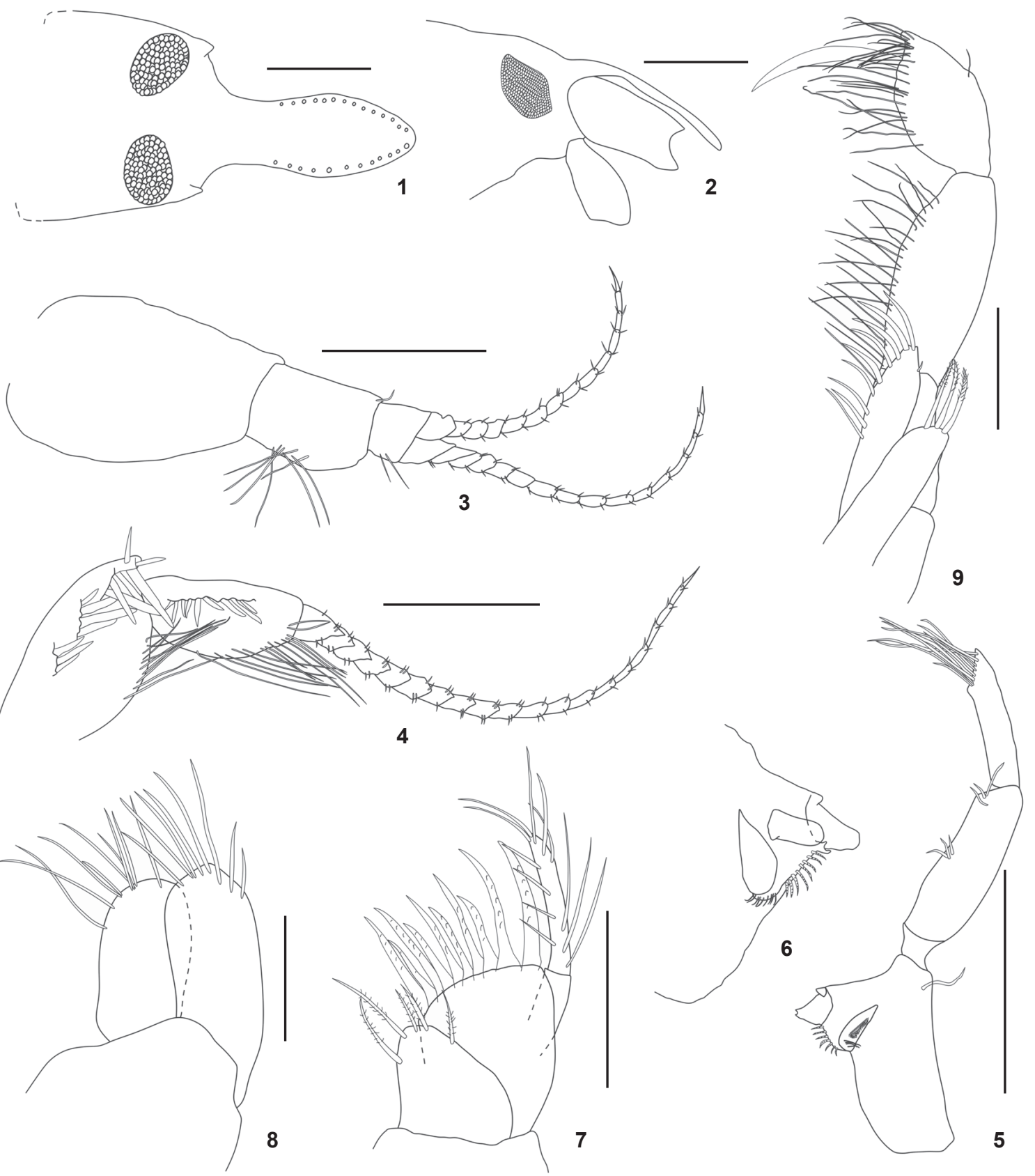

Figures 1-9. Metharpinia taylorae sp. nov., holotype, female: (1) head, dorsal view; (2) head, lateral view; (3) antenna 1; (4) antenna 2; (5) right mandible; (6) left mandible; (7) maxilla 1; (8) maxilla 2; (9) maxilliped. Scale bars: $0.2 \mathrm{~mm}$ for maxilla 1-2; $0.5 \mathrm{~mm}$ for the remainder.

slightly curved upwards; dactylus curved, simple, slightly longer than palm. Pereopod 3 (Fig. 12), coxa subrectangular, about 1.7X longer than wide, ventral margin subrounded, without setae; basis, about $3 \mathrm{X}$ longer than wide, subrectangular, posterior margin with five long slender setae, anterior margin with seven small setae; ischium small, posteroventral corner with one slender setae; merus elongate, about twice longer than wide, subrectangular, posterior margin with three sets of long setae (2-1-2), posterodistal corner with a row of seven long setae, anterodistal corner with two small setae; carpus broad, about 1.2X longer than wide ventral margin setose; propodus elongate, about $3.8 \mathrm{X}$ longer than wide, posterior margin with 
eight sets of setae (6-2-3-2-5-2-2-1); dactylus simple, about $0.4 \mathrm{X}$ as long as propodus. Pereopod 4 (Fig. 13), coxa suboval, ventral margin rounded, posteroventral corner with two small slender setae; basis, 3.2X longer than wide, posterior margin with five long slender setae, posteroventral corner with three slender setae; ischium, small, posterior margin with five slender setae; merus, elongate, about $2.1 \mathrm{X}$ longer than wide, subrectangular, anterodistal corner with two slender setae, posterior margin with eight pairs of long slender setae, posterodistal corner with four slender setae; carpus, broad, about 1.4X longer than wide, posterior margin setose; propodus elongate, about 3.9X longer than wide, posterior margin with four sets of slender setae (4-2-4-2); dactylus robust, simple, about half length of propodus. Pereopod 5 (Fig. 14), coxa wider than long, with two lobes, posterior lobe with sinuous ventral margin, deeply produced, bearing four slender setae; basis, about twice longer than wide, subrectangular, posteriorly slightly expanded, anterior margin setose, anterodistal corner with five slender setae, posterior margin naked and slightly concave; ischium, small, naked; merus, about $1.7 \mathrm{X}$ longer than wide posteriorly expanded, anterior margin with one slender seta, posterior margin setose; carpus, about 1.4X longer than wide, anterior margin setose, posterior margin with three sets of slender setae (5-1-11), posteroventral corner with two long plumose setae; propodus, about $4.1 \mathrm{X}$ longer than wide, anterior margin with two sets of slender setae (4-5), anteroventral corner with five slender setae, posteroventral corner with six setae; dactylus slender, simple, about half length of propodus. Pereopod 6 (Fig. 15), coxa with a subacute posterior lobe, posterior margin setose; basis, about $1.2 \mathrm{X}$ longer than wide expanded posteriorly, anterior margin setose, posterior margin naked; ischium, small, naked, about twice wider than long; merus, wide, about $1.6 \mathrm{X}$ longer than wide anterior margin with four sets of setae (2-4-2-4), posterior margin with four sets of setae (3-4-5-5); carpus, about 2.2X longer than wide, anterior margin with three sets of setae (2-2-4), posterior margin with four sets of setae (1-2-2-6); propodus, elongate, about $8.2 \mathrm{X}$ longer than wide, anterior margin with two sets of setae (3-2), anterodistal corner with two slender setae and one stout setae with accessory seta, posterior margin with six sets of setae (32-2-2-3-1), posteroventral corner with five slender setae; dactylus, about 0.3X as long as propodus. Pereopod 7 (Fig. 16), coxa, posterior margin minutely setose; basis strongly expanded posteriorly, posterior margin serrate, posteroventral lobe rounded, smooth, and naked; ischium small, anterodistal corner with one slender seta; merus, anterior margin with two sets of setae (2-2), posterior margin with four sets of setae (1-2$2-2)$; carpus, about $1.5 \mathrm{X}$ longer than wide, anterior margin with four slender setae, anterodistal corner with a set of four slender setae, posterior margin with two sets of setae (3-2), posteroventral corner with a set of four slender setae; propodus, about $4 \mathrm{X}$ longer than wide, anterior margin with one slender seta, anterodistal corner with one slender seta, posterior mar- gin with two sets of setae (2-4), posteroventral corner with three slender setae; dactylus slightly robust, about $0.6 \mathrm{X}$ as long as propodus.

Epimeral plate 1 (Fig. 17), anterior margin with one slender seta, ventral margin with two slender and 13 plumose setae, posterior margin slightly serrate, with 11 long slender setae, posteroventral corner rounded. Epimeral plate 2 (Fig. 18), anterior margin naked, ventral margin with seven medium and four long plumose submarginal setae, posterior margin with slightly serrate, with 10 long slender setae, posteroventral corner subrounded. Epimeral plate 3 (Fig. 19), anterior margin with seven small slender setae, ventral margin with five submarginal pectinate setae, posterior margin with slightly serrate, with 13 long slender setae, posteroventral corner broadly rounded. Uropod 1 (Fig. 20), peduncle elongated, about 2.1X longer than wide, dorsal margin with four stout setae; outer ramus slightly longer than inner ramus, about 7.9X longer than wide, dorsal margin with 11 stout setae, plus one subapical long stout seta; inner ramus subequal in length to peduncle, about $6 \mathrm{X}$ longer than wide, dorsal margin with three stout setae, plus one subapical long stout seta. Uropod 2 (Fig. 21), peduncle about 1.7X longer than wide, dorsal margin with three stout setae, dorsoapical corner with one stout setae, apicolateral corner with one stout setae; outer ramus, slightly longer than inner ramus, about 6.7X longer than wide, dorsal margin with nine stout setae, plus one subapical long stout seta; inner ramus, about $1.2 \mathrm{X}$ longer than peduncle, about 5.7X longer than wide, dorsal margin naked, with one subapical long stout seta. Urosomite 3 (Fig. 22) without dorsal hook. Uropod 3 (Fig. 23), peduncle short, about $1.3 \mathrm{X}$ longer than wide, apicolateral corner with five stout setae; outer ramus 2-articulate, about 1.6X longer than inner ramus, about $2.7 \mathrm{X}$ longer than peduncle, article 1 elongated, about 4.7X longer than wide, about 3.4X longer than article 2 , dorsal margin bearing two stout setae and one small distal seta, ventral margin with one long distal plumose seta; article 2, about 4.7X longer than wide, bearing two apical slender setae; inner ramus, about $1.7 \mathrm{X}$ longer than peduncle, about 4.7X longer than wide, bearing seven apical and one subapical stout plumose setae. Male uropod 3 (Fig. 24), peduncle short, about 2.2X longer than wide, apicolateral corner with three stout setae with accessory setae, lateral margin with one stout setae with accessory setae and one short setae, facial margin with one slender setae; outer ramus 2-articulate, about 1.1X longer than inner ramus, about 2,2X longer than peduncle, article 1 elongated, about $4.6 \mathrm{X}$ longer than wide, about $4.4 \mathrm{X}$ longer than article 2, dorsal margin bearing two sets of stout setae with accessory setae (2-2) and three stout setae with accessory setae distally, ventral margin with five long plumose setae; article 2, about 3.4X longer than wide, bearing two apical slender setae; inner ramus, about 1.9X longer than peduncle, about 5.6X longer than wide, dorsal margin bearing two long plumose setae, ventral margin bearing five long plumose setae and one short simple setae, apical margin bearing two long plumose setae. Telson (Fig. 


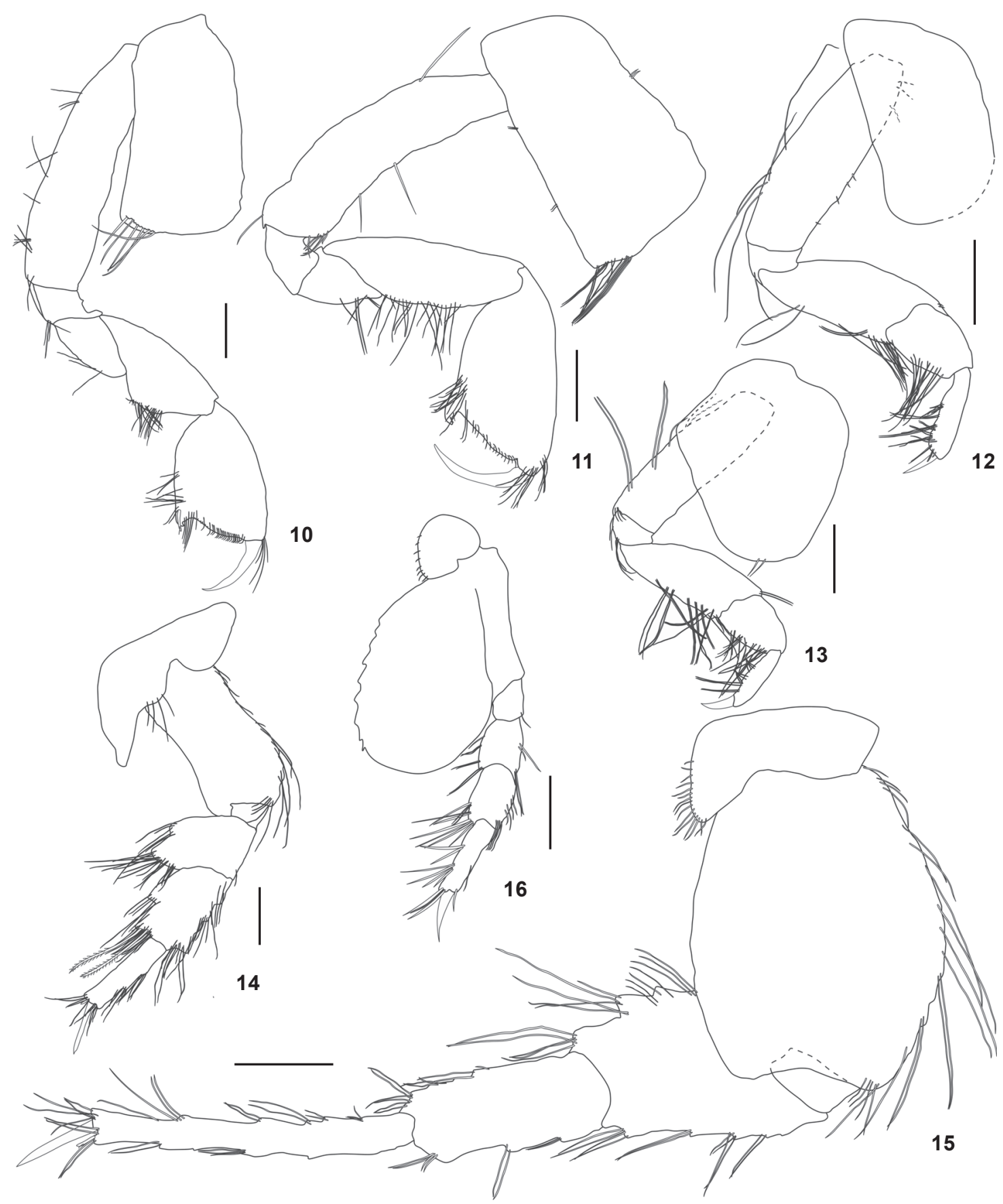

Figures 10-16. Metharpinia taylorae sp. nov., holotype, female: (10) gnathopod 1; (11) gnathopod 2; (12) pereopod 3; (13) pereopod 4; (14) pereopod 5; (15) pereopod 6; (16) pereopod 7. Scale bars: $1.0 \mathrm{~mm}$ for gnathopods 1-2; $0.5 \mathrm{~mm}$ for the remainder.

25), about $1.3 \mathrm{X}$ longer than wide, deeply cleft, about $90 \%$ of its length, apical margin truncate with blunt cusp, each lobe with one lateral small plumose seta, subapical margin bearing five slender setae on each lobe, apex naked.
Material examined. Holotype female, $8.5 \mathrm{~mm}$, BraziL, Rio

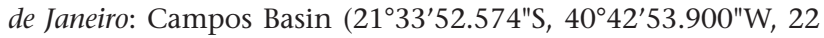
m depth), 10 March 2009, R/V Gyre leg., MNRJ 477. Allotype male, BrazIL, Espírito Santo: Campos Basin (2111'0,850"S, 

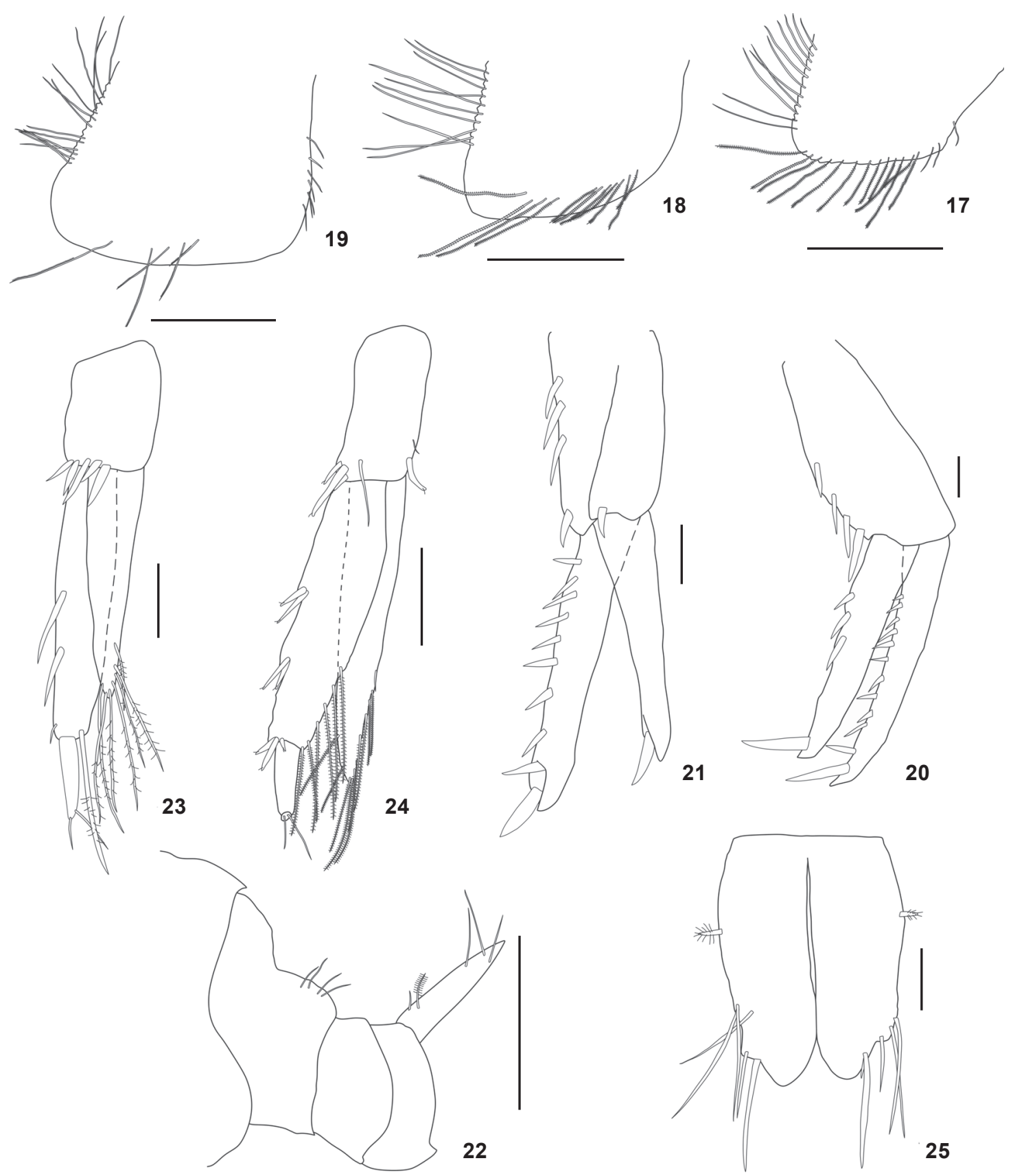

21
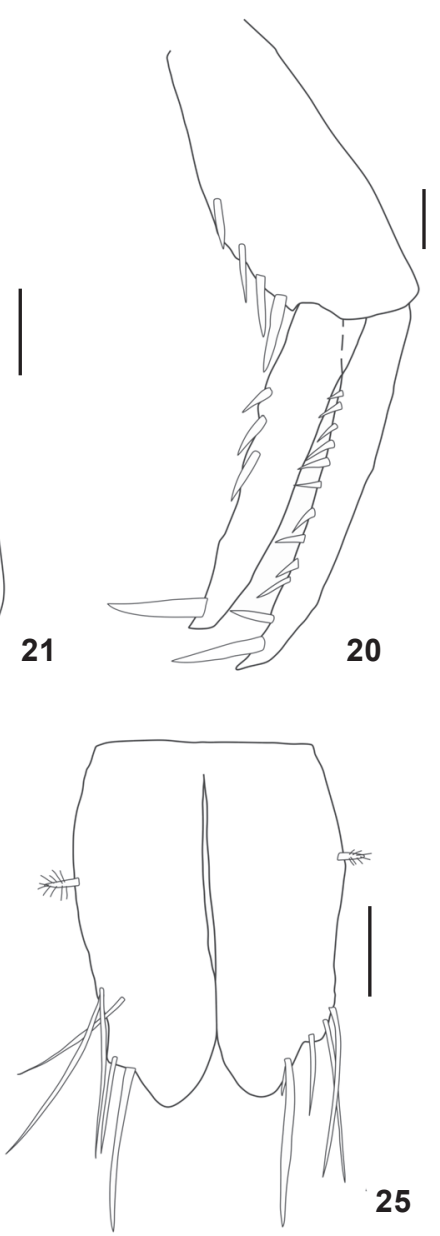

Figures 17-25. Metharpinia taylorae sp. nov., holotype, female: (17) epimeral plate $1 ;(18)$ epimeral plate 2 ; (19) epimeral plate 3; (20) uropod $1 ;(21)$ uropod $2 ;(22)$ urosomite $3 ;(23)$ uropod $3 ;(25)$ telson; paratype, male: (24) uropod 3. Scale bars: 0.2 for male and female uropod $3 ; 0.5 \mathrm{~mm}$ for the remainder.

40²8'27.125"W, 26 m depth); 5 March 2009, R/V Gyre leg., MNRJ 479. Paratypes: 1 male, BraziL, Espírito Santo: Campos Basin (21ำ1'51.743"S, 40³0'59.011"W, 29 m depth), 07 March 2009, R/V Gyre leg., MNRJ 478; 1 male and 12 juveniles, Rio de Janeiro: Campos Basin (213' 53.096"S, 4042'55.466"W, 21 m depth, van
Veen), 10 March 2009, R/V Gyre leg., MNRJ 480; 2 females and 13 juveniles, $\left(21^{\circ} 39^{\prime} 11.066^{\prime \prime} \mathrm{S}, 40^{\circ} 48^{\prime} 49.898^{\prime \prime} \mathrm{W}, 21 \mathrm{~m}\right.$ depth, van Veen), 11 March 2009, R/V Gyre leg., MNRJ 481; 1 ovigerous female, 1 male and 8 juveniles, $\left(21^{\circ} 39^{\prime} 9.790^{\prime \prime} \mathrm{S}, 40^{\circ} 48^{\prime} 50.234^{\prime \prime} \mathrm{W}\right.$, 22 m depth, van Veen), 19 July 2009, R/V Gyre leg., MNRJ 482. 
Geographic distribution. Brazil, north coast of Rio de Janeiro State and south coast Espírito Santo State, Campos Basin, off the mouth of the Paraíba do Sul River (Fig. 26). Type locality: $21^{\circ} 33^{\prime} 52.574^{\prime \prime S}, 40^{\circ} 42^{\prime} 53.900^{\prime \prime} \mathrm{W}$.

Bathymetric range. Collected from 21 to $29 \mathrm{~m}$ depth.

Etymology. The species epithet, taylorae, is dedicated to Dr. Joanne Taylor, from the Museum Victoria, Australia, to honor her important contributions to the knowledge on the amphipod family Phoxocephalidae.

\section{DISCUSSION}

Metharpinia taylorae sp. nov. shares the diagnostic characters of the genus, such as the constricted, narrow, spatulated and elongated rostrum, and uropod 3 with one of rami longer than peduncle, bearing article 2 on outer ramus, with two apical setae (BARnard \& Karaman 1991). Although M. taylorae sp. nov. shares some characters with species of Microphoxus (see comparison between the two genera in Alonso DE Pina 2003a), we placed the new species in Metharpinia because, for the most part, it fits the diagnosis of this genus.

The new species is easily distinguished from $M$. dentiurosoma and from $M$. grandirama by in lacking the dorsal hook on urosomite 3, a unique feature of M. dentiurosoma and M. grandirama (Alonso DE PINA 2003a).

Metharpinia taylorae sp. nov. differs from M. protuberantis by the following combination of characters (M. protuberantis characters in parenthesis): rostrum strongly constricted and highly developed (weakly constricted, poorly developed); gnathopod 2, basis, slightly elongate (strongly elongate); pereopod 5, coxa posterior lobe deeply produced (slightly produced); epimeral plate 3, posteroventral corner broadly rounded (strongly produced into a large tooth) (Alonso de PINA 2001).

Metharpinia taylorae sp. nov. differs from M. coronadoi by the following characters (M. coronadoi characters in parenthesis): coxa 1 weakly expanded anteriorly (anterior margin straight); right lacinia mobilis absent (present); left lacinia mobilis well developed, apically smooth and subrounded (with 2-3 teeth plus 1-2 accessory teeth); epimeral plate 3, posteroventral margin rounded (rounded-quadrate) (BARNARD 1980).

Metharpinia taylorae sp. nov. differs from $M$. jonesi by the following characters (M. jonesi characters in parenthesis): pereopods 3 and 4 very similar in shape (pereopod 4 stouter and longer than pereopod 3); epimeral plate 3 , ventral margin with five submarginal pectinate setae (with large tooth, ventral margin with 4 setae) (BARNARD 1963).

Metharpinia taylorae sp. nov. differs from M. floridana by the following characters ( $M$. floridana characters in parenthesis): epimeral plate 2 rounded (rounded-subquadrate); telson, both male and female, each lobe with 1 lateral small plumose seta (each lobe with 1 lateral and 1 subapical plumose setae) (Shoemaker 1933).

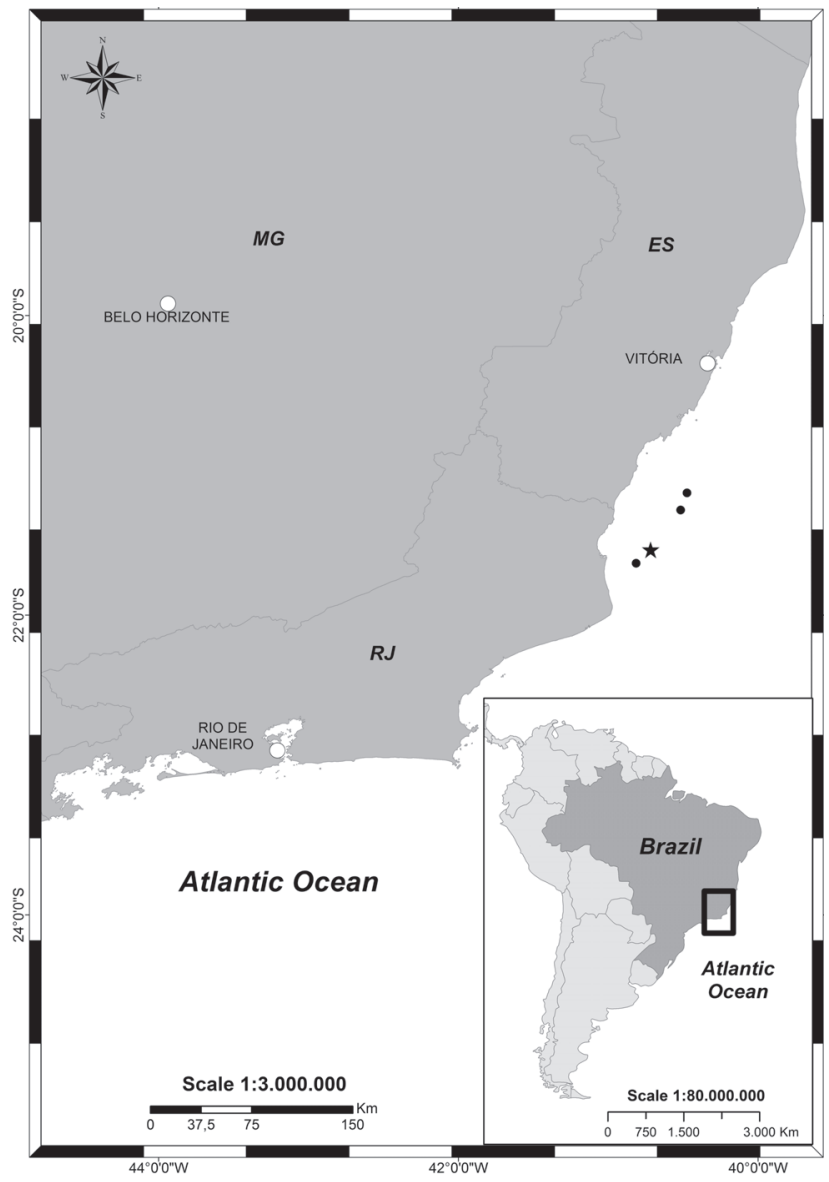

Figure 26. Distribution of Metharpinia taylorae sp. nov. Star: type locality, $21^{\circ} 33^{\prime} 52.574^{\prime \prime S}, 40^{\circ} 42^{\prime} 53.900^{\prime \prime W}$; Circle: ocurrence of paratypes. RJ: Rio de Janeiro State; ES: Espírito Santo State; MG: Minas Gerais State (Distribution map by Danielle P. Cintra).

Metharpinia taylorae sp. nov. differs from M. oripacifica by (M. oripacifica characters in parenthesis): right lacinia mobilis absent (present); left lacinia mobilis well developed, apically smooth and subrounded (with five teeth, middle teeth scarcely shortened); telson, each lobe bearing 5 slender setae (dorsolateral brush of 7 setae) (BARNARD 1980).

Metharpinia iado, recorded from Argentina, is probably the most different from $M$. taylorae sp. nov., due to the following characters ( $M$. iado characters in parenthesis): left mandible, lacinia mobilis apically smooth and blunt (multi-cuspidate); maxilla 2, inner plate without plumose setae (with apical and medial plumose setae), outer plate, outer margin naked (setose); maxilliped, inner plate, with three apical plumose setae (eight apical plumose setae, plus one stout seta); gnathopods 1-2 weakly setose (strongly setose), palm of gnathopods 1-2 sinuous (almost straight); pereopod 5, coxa posterior lobe produced and subacute (not produced, round), pereopods 5-6, merus and car- 
pus without facial setae (with facial sets of stout setae); telson, deeply cleft, about 90\% (three-quarters cleft) (Alonso DE PINA 2003b).

The description of the type-species of Metharpinia, $M$. longirostris, is insufficient and the species is poorly illustrated. However, we can distinguish the new species from it by the following characters (characters of $M$. longirostris within parenthesis): pereopods 5-6 without facial setae (with facial setae); posteroventral lobe of basis of pereopod 7 round (truncated); coxa 4, posteroventral corner with two small slender setae (ventral and posterior margins setose); each telson lobe with one lateral small plumose seta, apex naked (without lateral plumose setae, apex setose) (Schellenberg 1931, Barnard 1980).

Two characteristics are exclusive of the new species among the representatives of Metharpinia: palp of maxilla 1 slender, article 2 bearing slender setae on both sides and at apical margin; and the lacinia mobilis absent in right mandible and smooth and subrounded in the left mandible.

\section{ACKNOWLEDGMENTS}

We thank Coordenação de Aperfeiçoamento de Pessoal de Nível Superior (CAPES) and Fundação Carlos Chagas Filho de Amparo à Pesquisa do Estado do Rio de Janeiro (FAPERJ) for the financial support and fellowships. The material examined was provided by Centro de Pesquisas e Desenvolvimento Leopoldo Américo Miguez de Mello (CENPES-PETROBRAS). The distribution map was made by Danielle P. Cintra from Instituto de Geociências, Universidade Federal do Rio de Janeiro (IGEO-UFRJ).

\section{LITERATURE CITED}

Alonso de Pina, GM (2001) Two new phoxocephalids (Crustacea: Amphipoda: Phoxocephalidae) from the south-west Atlantic. Journal of Natural History 35: 515-537.

Alonso de PINa GM (2003a) Two new species of Metharpinia Schellenberg (Amphipoda: Phoxocephalidae) from the southwest Atlantic. Journal of Natural History 37: 2521-2545.

Alonso de PINA GM (2003b) A new species of Phoxocephalidae and some other records of sand-borrowing Amphipoda (Crustacea) from Argentina. Journal of Natural History 37: 1029-1057.

Submitted: 30 June 2014

Received in revised form: 2 December 2014

Accepted: 7 December 2014

Editorial responsibility: Marcos D.S. Tavares
BARNARD JL (1963) Relationship of benthic Amphipoda to invertebrate communities of inshore sublittoral sands of southern California. Pacific Naturalist 3(15): 437-467.

BARNARD JL (1980) Revision of Metharpinia and Microphoxus (marine phoxocephalid Amphipoda from the Americas). Proceedings of the Biological Society of Washington 93(1): 104-135.

Barnard JL, DRUmmond MM (1978) Gammaridean Amphipoda of Australia, part III: The Phoxocephalidae. Smithsonian Contributions to Zoology 245: 1-551.

Barnard JL, Drummond MM (1982) Gammaridean Amphipoda of Australia, Part V: Superfamily Haustorioidea. Smithsonian Contributions to Zoology 360: 1-148.

Barnard JL, Karaman GS (1991) The Families and Genera of Marine Gammaridean Amphipoda (Except Marine Gammaroidea). Records of the Australian Museum 13: 1-866.

Horton T, De Broyer C (2014) Phoxocephalidae Sars, 1891. In: Horton T, Lowry J, Broyer C De (Ed.). World Amphipoda Database. Available online at: http://www.marinespecies.org/ aphia.php?p=taxdetails\&id=101403 [Accessed: 22 May 2014]

Hurley DE (1954) Studies on the New Zealand Amphipodan Fauna 3. The Family Phoxocephalidae. Transactions of the Royal Society of New Zealand 81: 579-599.

Poore AGB, Lowry JK (1997) New ampithoid amphipods from Port Jackson, New South Wales, Australia (Crustacea: Amphipoda: Ampithoidae). Invertebrate Taxonomy 11: 897-941.

Senna AR, Souza-Filho JF (2011) A new species of Pseudharpinia (Amphipoda: Haustorioidea: Phoxocephalidae) from Southeastern Brazilian continental shelf. Nauplius 19(1): 7-16.

Schellenberg A (1931) Gammariden und Caprelliden des Magellangebietes, Südgeorgiens und der Westantarktis. Further Zoological Results of the Swedish Antarctic Expedition 1901-1903 2(6): 1-290.

Shommaker CR (1933) Amphipoda from Florida and the West Indies. American Museum Novitates 598: 1-24.

WatLING L (1989) A classification of crustacean setae based on the homology concept, p. 15-26. In: Felgenhauer BE, Thistle AB, Watling L (Ed.) Functional Morphology of Feeding and Grooming in Crustacea. New York, CRC Press, Crustacean Issues, vol. 6. 